found elevated plasma 11-OHCS in depressed subjects as compared with controls at all three sampling times. Bridges and Jones (1966), who also observed plasma 11-OHCS levels over 24 hours, reported lower values in the depressed patients as compared with controls at two out of their three sampling times. Knapp et al. (1967) took a series of seven samples from a group of depressed patients at four-hourly intervals beginning at $\mathbf{0 8 . 0 0}$ hours, and found significantly elevated 11-OHCS levels at 04.00 hours. Conroy et al. (1968) reported higher mean values in a group of five affective psychotics as compared with two other groups of psychotic patients in samples taken at approximately $15.00,22.00$. 07.00, 10.00, and 15.00 hours.

The present results provide further evidence that plasma corticosteroid values tend to be raised in depressive illness and, because serial samples were taken, it may be seen that this rise may be present throughout the 24 hours, but is perhaps (see Fig. 1) more readily observed in late evening or night samples and may even be obscured in morning blood samples. It also appears that the phase or timing of the circadian rhythm of the plasma corticosteroids may be upset in some depressed patients. In this respect it is interesting to note that Doig et al. (1966), who measured plasma 11-OHCS values at $24.00,03.00$, and 06.00 hours, recorded peak levels at 03.00 hours in 7 out of 10 depressed patients studied, and that on recovery five out of the six cases they were able to re-examine showed a shift in peak values to 06.00 hours. None the less, a circadian rhythm of corticosteroid secretion persists even in the acutely depressed state, as is well shown in the case depicted in Fig. 2 ; and in another study we did not note any evidence of phase-shifting in samples taken at about 22.00 and 07.00 hours (Conroy et al., 1968). The tendency for plasma 11-OHCS levels to fall on clinical recovery (Gibbons and McHugh, 1962 ; Bridges and Jones, 1966; Hullin et al., 1967) is also illustrated in this patient. Here again this might not have been so clearly evident had serial samples not been taken.

Little work seems to have been done on plasma 11-OHCS levels in schizophrenia. Sachar et al. (1963) have, however, reported marked rises in urinary 17-hydroxycorticosteroids during acute schizophrenic reactions. The night and early morning pattern of plasma 11-OHCS in our schizophrenic sub- group may almost be described as supernormal, with a fall to zero levels in four out of five patients at $\mathbf{0 2 . 0 0}$ hours followed by a very sharp rise to high values at 06.00 hours.

The most remarkable finding is the close similarity of the plasma corticosteroid rhythm to that observed in healthy subjects, even in patients with gross psychiatric abnormality, and, most notably, in one who was continuously stuporous.

\section{REFERENCES}

Bliss, E. L., Clark, L. D., and West, C. D. (1959). Arch. Neurol. Psychiat. (Chic.), 81, 348

Bliss, E. L., Sandberg, A. A., Nelson, D. H., and Eik-Ness, K. (1953). 7. clin. Invest., 32, 818.

Board, F., Persky, H., and Hamburg, D. A. (1956). Psychosom. Med., 18,324

Board, F., Wadeson, R.. and Persky, H. (1957). Arch. Neurol. Psychiat. (Chic.), 78, 612.

Bridges, P. K., and Jones, M. T. (1966). Brit. F. Psychiat., 112, 1257

Brooksbank, B. .W. L., and Coppen, A. (1967). Brit. F. Psychiat., 113,

Bush, I. (1954). Kecent Progr. Hormone Res., 9, 449.

Conroy, R. T. W. L., Elliott, A. L., Hughes, B. D., and Mills, J. N. (1968). o. Physiol. (Lond.), 196, 129P.

Doig, R. J., Mummery, R. V., Wills, M. R., and Elkes, A. (1966). Brit. 7. Psychiat., 112, 1263.

Eik-Ness, K., Nelson, D. H., and Samuels, L. T. (1953). Y. clin. Endocr., 13, 1280 .

Elithorn, A., Bridges, P. K., Lobban, M. C., and Tredre, B. E. (1966). Brit. med. F., 2, 1620 .

Gibbons, J. L. (1964). Arch. gen. Psychiat., 10, 572

Gibbons, J. L. (1964). Arch. gen. Psychiat., 10, 572.

Gibbons, J. L., and McHugh, P. R. (1962). 7. psychiat. Res

Gjessing, R. (1936). Arch. Psychiat. Nervenkr., 104, 355.

Hoagland, H. et al. (1953). Arch. Neurol. Psychiat. (Chic.), 69, 470.

Hullin, R. P., Bailey, A. D., McDonald, R., Dransfield, G. A., and Milne, H. B. (1967). Brit. F. Psychiat., 113, 593.

Knapp, M. S., Keane, P. M., and Wright, J. G. (1967). Brit. med. J., $2,27$.

Lobban, M., Tredre, B., Elithorn, A., and Bridges, P. (1963). Nature (Lond.), 199, 667.

Mattingly, D. (1962). \%. clin. Path., 15, 374

McClure, D. J. (1966). \%. psychosom. Res., io, 189

Perkof, G. T., et al. (1959). Y. clin. Endocr., 19, 432

Perkof, G. T.̈ et al. (1959). F. clin. Endoc

Randrup, A., and Munkvad, I. (1966). Brit. F. Psychiat., 112, 173.

Reiss, M. (1953). Int. Rec. Med., 166, 196

Sachar, E. J., Mason, J. W., Kolmer, H. S., and Artiss, K. L. (1963). Psychosom. Med., 25, 510 .

Spencer-Peet, J., Daly, J. R., and Smith, V. (1965). J. Endocr., 31, 235. Sweat, M. L. (1954). Analyt. Chem., 26, 773.

\title{
Trial of Phenoxymethylpenicillin, Phenethicillin, and Lincomycin in Treatment of Staphylococcal Sepsis in a Casualty Department
}

\author{
D. J. E. PRICE,* M.B., B.S., F.R.C.S. ; F. W. O’GRADY, † M.D., M.SC., M.C.PATH. \\ R. A. SHOOTER, $\ddagger$ M.D., M.R.C.P., F.C.PATH. ; P. C. WEAVER,§ M.B., B.S., F.R.C.S.ED.
}

Brit. med. F., 1968, 3, 407-409

\begin{abstract}
Summary: A comparative trial of phenoxymethylpenicillin (penicillin V), phenethicillin (Broxil), and lincomycin (Lincocin) against superficial staphylococcal infections seen in a casualty department showed no difference in the efficacy of the three agents, though half the staphylococci isolated were resistant to penicillin. Possible reasons include the fact that antibiotic treatment may not affect superficial staphylococcal infections, or that the organisms concerned may have been weak formers of penicillinase.
\end{abstract}

Falf the patients treated with lincomycin complained of diarrboea and $5 \%$ of those treated with phenethicillin suffered from nausea.

\begin{abstract}
Introduction
In this hospital it is usual to prescribe penicillin for the antibiotic treatment of patients seen in the casualty department with staphylococcal sepsis. If the lesion is open the organism is cultured and, if necessary, the antibiotic is changed to one appropriate to the bacteriological sensitivities. Phenoxymethylpenicillin (penicillin V) by mouth has been found to be almost as satisfactory as penicillin by injection (Burn et al.,

\footnotetext{
- Institute of Neurological Science, Rillearn Hospital, near Glasgow. Formerly Sorting Officer, St. Bartholomew's Hospital, London E.C.1. 5 St. Albans City Hospital, 10 Gombards, St. Albans, Herts. Formerly Sorting Officer, St. Bartholomew's Hospital, London E.C.1.
} † Professor of Bacteriology, St. Bartholomew's Hospital, London E.C.1. ₹ Professor of Bacteriology, St. Bartholomew's Hospital, London E.C.1.
\end{abstract}


1957), and it has been the practice to use intramuscular penicillin only for the most severe infections. In the work reported here the opportunity has been taken to compare the results obtained in the treatment of staphylococcal sepsis with phenoxymethylpenicillin, phenethicillin (Broxil), and lincomycin (Lincocin). Lincomycin was chosen as it is active against penicillin-resistant organisms.

\section{Materials and Methods}

Patients attending with acute infections of the skin and subcutaneous tissues were included unless they needed incision, were diabetic, were children under the age of 10 , had already begun treatment with an antibiotic, had infections that were draining well, or were known to be receiving steroids. They were seen three or four times a week and relevant details were recorded on forms attached to their notes. Swabs were taken from open lesions, which were then dressed with $12 \frac{1}{2} \%$ sodium sulphate. Closed lesions were treated with kaolin poultices.

Each patient was given a prescription for a fictitious drug, multimycin, six-hourly for seven days. The pharmacist dispensed one of the antibiotics in the trial according to a datelinked code that only she knew. The dosages used were phenoxymethylpenicillin and phenethicillin $250 \mathrm{mg}$., and lincomycin $500 \mathrm{mg}$.

\section{Results}

During this trial 291 patients were treated with an antibiotic but only 221 attended for assessment. Of the patients who did not attend 23 had been given phenoxymethylpenicillin, 21 phenethicillin, and 26 lincomycin. Table I shows the numbers treated by each drug and some of the clinical findings. There was no appreciable difference in the groups for severity of pain, the duration of symptoms before treatment, or the presence of lymphangitis. Table II shows the number of infections from which swabs were examined and the number from which staphylococci were isolated. Table III shows the results obtained with each drug; it will be seen that they did not differ to any significant extent. The half infected with penicillin-resistant staphylococci appeared to do no worse than those infected with sensitive strains.

TablB I.-Details of Patients

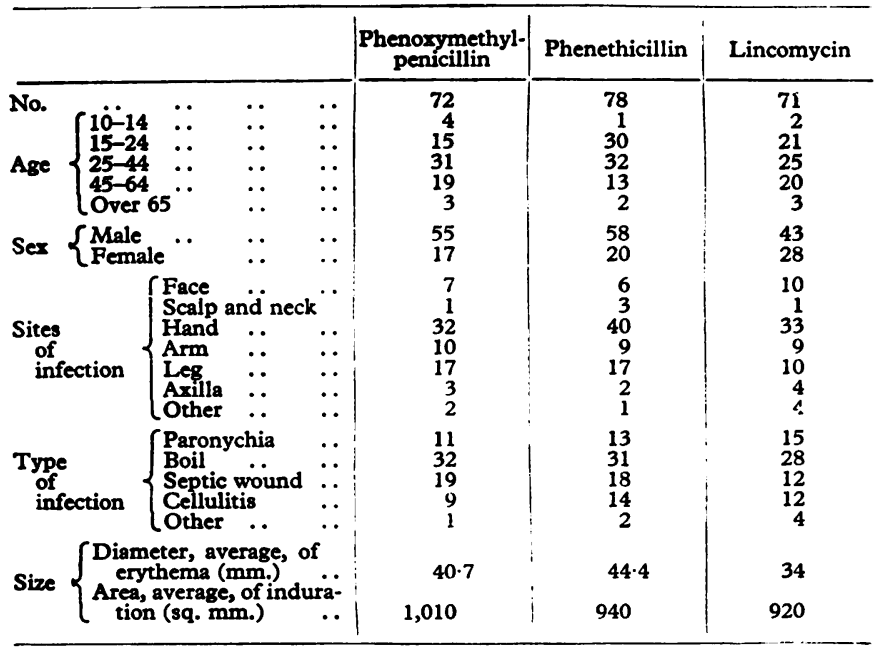

TABLB II.-Staphylococcal Isolated from Septic Lesions

\begin{tabular}{l|c|c|c|c}
\hline & $\begin{array}{c}\text { Phenoxymethyl- } \\
\text { penicillin }\end{array}$ & Phenethicillin & Lincomycin \\
\hline No. of swabs examined & $\ldots$ & 45 & 41 & 39 \\
Staph. aureus isolated & 46 & 33 & 36 \\
No. resistant to penicillin & $\cdots$ & 20 & 18 & 18 \\
\hline
\end{tabular}

Patients were questioned about any side-effects of treatment. There were few, except for looseness of the bowels. Of those receiving phenoxymethylpenicillin $8 \%$ complained of this upset, and of those having phenethicillin $13 \%$. It was a common complaint with lincomycin : $49 \%$ of the patients suffered from it, and in three it became so severe that treatment was stopped. Phenethicillin produced nausea in $5 \%$ of the patients (twice as of ten as the other two drugs). It was severe enough to require withdrawal of treatment in two patients.

Staphylococcus aureus was isolated from 333 patients, seen before, during, and after the trial. Of these strains $50 \%$ were resistant to penicillin.

TABLE III.-Results of Treatment

\begin{tabular}{|c|c|c|c|}
\hline & $\left|\begin{array}{c}\text { Phenoxymethyl- } \\
\text { penicillin }\end{array}\right|$ & Phenethicillin & Lincomycin \\
\hline $\begin{array}{l}\text { No. of patients } \\
\text { Average days to relief of pain } \\
\text { Average days to loss of tender. }\end{array}$ & $2 \cdot 8(1-11 \cdot 5)$ & $2 \cdot 6 \stackrel{78}{(1-7 \cdot 5)}$ & $2.6 \stackrel{71}{(0.5-8.5)}$ \\
\hline $\begin{array}{l}\text { neas } \\
\text { Healing time, average in days } \\
\text { fer to another antibiotic: } \\
\text { As result of failure to res- } \\
\text { pond after at least } 5 \text { days' }\end{array}$ & $\begin{array}{c}6(1-12) \\
7.9(2 \cdot 5-24)\end{array}$ & $\begin{array}{l}6 \cdot 1(1-22) \\
8(2 \cdot 5-22)\end{array}$ & $\begin{array}{l}5.7(1-12) \\
7.9(2-22)\end{array}$ \\
\hline $\begin{array}{l}\text { On account of severe side- } \\
\text { reactions }\end{array}$ & $\begin{array}{l}5 \\
1\end{array}$ & $\stackrel{\frac{1}{2}}{\text { (vomiting) }}$ & $\begin{array}{c}2 \\
3 \\
\text { (diarhoea) } \\
\text { 2nd or 6th day. } \\
1 \text { admitted to } \\
\text { ward. Acute } \\
\text { exacerbation of } \\
\text { diverticulitis }\end{array}$ \\
\hline $\begin{array}{l}\text { No. requiring incision during } \\
\text { course of treatment (ex- } \\
\text { cluded) } \\
\text {.. }\end{array}$ & 3 & 5 & 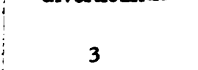 \\
\hline
\end{tabular}

\section{Discussion}

In reports from our casualty department in 1949, 1952, 1955, 1957, and 1960 the percentage of staphylococci resistant to penicillin was 6, 16, 21, 25, and 39 (MacFarlane et al., 1960). The present figure of $50 \%$ shows that the increase is continuing.

We encountered a much higher incidence of diarrhoea in patients receiving lincomycin than the 10-20\% described by other workers (Harnecker et al., 1963 ; Geddes et al., 1964). It is known that taking a meal shortly before lincomycin can halve the peak serum levels (McCall et al., 1967). A six-hourly regimen prevents correlation with meals, and it may be that dosage between meals would have ensured better absorption and reduced the incidence of diarrhoea.

The results of this trial and a number of others conducted in this hospital are much alike, but they are all subject to the criticism that none of them included a group of patients from whom antibiotics were withheld. In a previous study of a group of patients with more serious superficial staphylococcal infections (the group of 310 included 80 carbuncles and 63 abscesses) penicillin-resistant staphylococcal infections appeared to respond to treatment with penicillin as well as infections caused by penicillin-sensitive staphylococci (Burn et al., 1957). This is confirmed by the present series and reinforced by the finding that the response was no different in patients treated with lincomycin, which is active against penicillin-resistant staphylococci. It may be that this is because antibiotic treatment does not materially affect the natural course of superficial staphylococcal infection, and a formal trial including an untreated control group may now be justified. An alternative and therapeutically important explanation lies in the finding by Richmond et al. (1964) that the ability to form large amounts of penicillinase is closely associated with resistance to other antibiotics. Only $6.3 \%$ of the 333 strains of Staph. aureus isolated in the present series were resistant to tetracycline. The remaining strains resistant to penicillin only may have been only weak penicillinase formers. If multiple resistant strains 
of staphylococci became common in outpatient departments the results of treatment with penicillin might be different.

We gratefully acknowledge the help of Mr. James O. Robinson, surgeon in charge of outpatients; the sisters and nursing staff of the casualty department ; Miss Y. E, Fillis, pharmacist, and Miss E. J. Armour, statistician, St. Bartholomew's Hospital, and Mr. G. Eastman, computer programmer, Birmingham Hospital Regional Board.
REFERENCES

Burn, J. I., Curwen, M. P., Huntsman, R. G., and Shooter, R. A. (1957). Brit. med. F., 2, 193.

Geddes, A. M., Sleet, R. A., and Murdoch, J. McC. (1964). Brit. med. 7., 2, 670 .

Harnecker, J.; Contreras, J., Gilabert, B., and Ubilla, V. (1963). Antimicrobial Agents and Chemotherapy, 204

McCall, C. E., Steigbigel, N. H., and Finland, M. (1967). Amer. 7. med. Sci., 254, 144 .

MacFarlane, D. A., Murrell, J. S., Shooter, R. A., and Curwen, M. P. (1960). Brit. med. \%., 2, 900 .

Richmond, M. H., Parker, M. T., Jevons, M. P., and John, M. (1964). Lancet, 1, 293.

\title{
X-linked Recessive Inheritance in the Ehlers-Danlos Syndrome*
}

\author{
P. BEIGHTON, $\dagger$ M.R.C.P., M.R.C.P.ED., D.C.H., D.T.M.\&H.
}

Brit. med. F., 1968, 3. 409-411

\begin{abstract}
Cummary: Two families are described in which the Ehlers-Danlos syndrome is apparently transmitted as an $\mathrm{X}$-linked recessive character. The results of tests for the $\mathrm{Xg}$ blood groups and for colour vision show that the locus for the Ehlers-Danlos syndrome is not close to that for the $\mathrm{Xg}$ groups nor very close to the locus for deutan colour-blindness.
\end{abstract}

The clinical features of this variety of the EhlersDanlos syndrome include considerable hyperextensibility of the skin and a bruising tendency.

\section{Introduction}

The Ehlers-Danlos syndrome is an uncommon genetically determined disorder of connective tissue which is usually inherited as an autosomal dominant character (McKusick, 1966a). The major features of the condition are joint hypermobility, skin hyperextensibility, and a tendency for the skin to split on minor trauma with the formation of thin, gaping scars. Other variable concomitants are a liability to frequent bruising and musculoskeletal, cardiovascular, and ocular abnormalities.

* This paper represents part of a thesis submitted for the M.D. of the University of London.

t Medical Registrar, St. Thomas's Hospital, London S.E.1. Present address: Dept. of Genetics, Johns Hopkins Hospital, Baltimore, U.S.A.

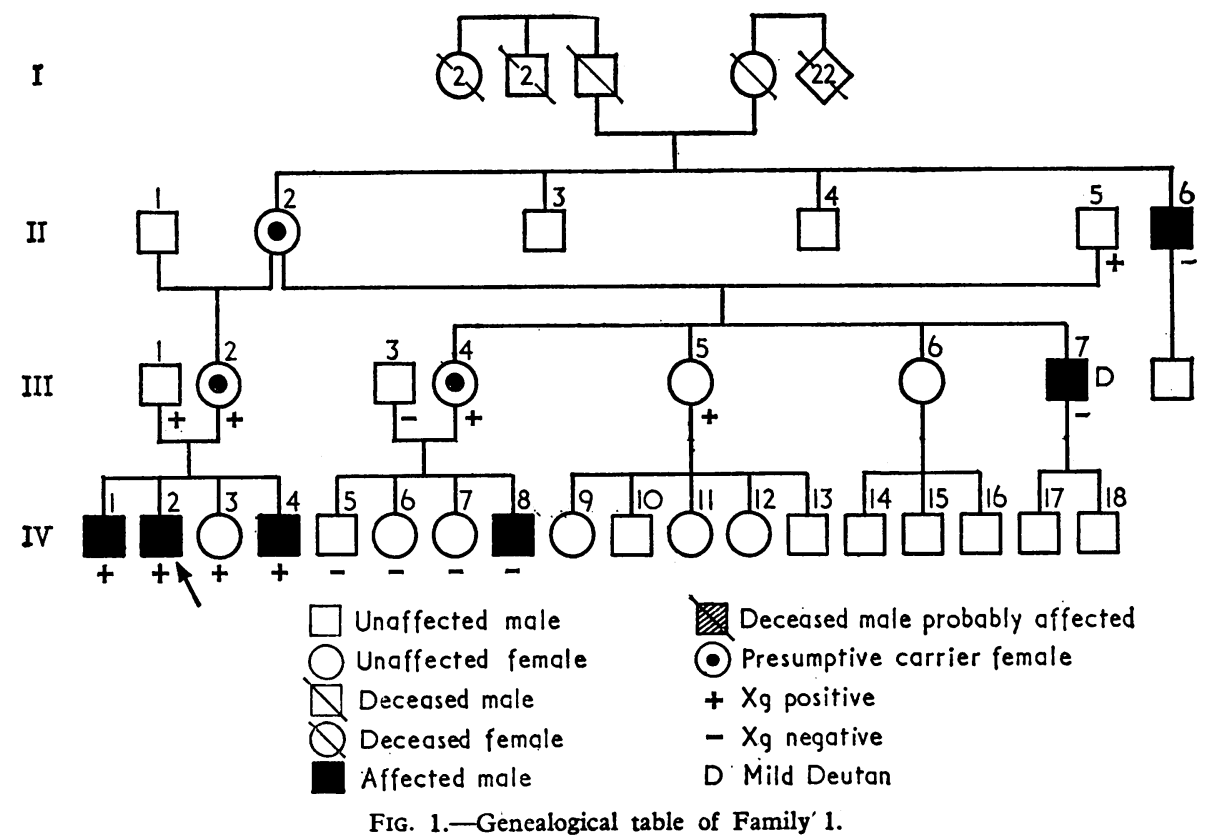

\section{Present Investigation}

During a survey in Southern England 100 patients with Ehlers-Danlos syndrome were fully examined. Twenty-nine of them had no affected relatives and were apparently sporadic cases. The other 71 were members of 22 separate families, and with the exception of the two described in this paper the condition was transmitted by the typical autosomal dominant mode of inheritance. In the family shown in Fig. 1 there are six affected males, and the pattern of inheritance is typical of an X-linked recessive condition. This mode of transmission was not mentioned by McKusick (1964) in his list of X-linked conditions, and it has apparently not been previously described in Ehlers-Danlos syndrome. All members of the family were examined with the exception of generation $I$ and the two males II 3 and II 4. However, the other members were adamant that neither of these brothers had any abnormality of the skin or joints.

In a second family in the series (Fig. 2) it was also possible that an $\mathrm{X}$-linked recessive mechanism of inheritance was operating. The only members of the family available for examination were the two affected brothers, III 1 and III 2 , their mother, II 5, and the children, IV 1 and IV 2. However, it was discovered from other sources that I 3 and I 4 had been well known for the loose joints in their hands and their remarkable facility for stretching their skin.

Once again the mode of transmission of the condition in this family is suggestive of the $\mathrm{X}$-linked recessive type inheritance, with the typical absence of male-to-male transmission.

In the series as a whole three other apparently sporadic males had phenotype features that corresponded to the $\mathrm{X}$-linked variety of the Ehlers-Danlos syndrome. However, in the absence of any positive family history it was impossible to make any definite assertion regarding their status. This must await the development of a biochemical method for recognition of this entity.

\section{Inheritance}

In these families there was no maleto-male transmission of the EhlersDanlos syndrome, while a total of four affected males had five unaffected sons. 